\title{
LEGISLACIÓN
}

PERÚ

\section{PROYECTO DE LEY QUE INCORPORA EN EL CÓDIGO PENAL EL DELITO CONTRA LA LIBERTAD RELIGIOSA Y DE CULTO}

\author{
EQUIPO REVISTA LATINOAMERICANA DE DERECHO Y RELIGIÓN
}

DOI: $10.7764 / R L D R .6 .671$

\section{Descripción del proyecto}

El día 21 de febrero de 2018, ingresó en el Congreso de la República del Perú el Proyecto de Ley que incorpora en el Código Penal el delito contra la libertad religiosa y de culto. ${ }^{1}$ El proyecto cuenta con 3 artículos, siendo el artículo $n^{\circ} 2$ el que incorpora dentro del Título IV del Código Penal peruano, sobre los delitos contra la libertad, el Capítulo XIII, delitos contra la Libertad Religiosa y de Culto.

Este capítulo, tipifica en dos artículos aquellos actos contra la libertad religiosa que "serán reprimidos con pena privativa de libertad no menor de dos ni mayor de cuatro años". ${ }^{2}$

\section{Fundamentos del proyecto}

El proyecto plantea los fundamentos normativos en que se basa, estos son: Tratados Internacionales: Declaración Universal de los Derechos Humanos; Declaración Americana de los derechos y deberes del hombre. La Constitución Política del Perú y la Ley 29.635, Ley de Libertad Religiosa.

${ }^{1}$ http://www.congreso.gob.pe/pley-2016-2021. Puede revisar el proyecto íntegro en el Boletín Jurídico Observatorio de libertad religiosa en América Latina y el Caribe. Febrero-marzo 2018

http://derechoyreligion.uc.cl/es/docman/boletin-juridico/2018-1/1275-boletin-juridico-febrero-marzo2018/file\#page $=219$

2 Ídem. 
Finalmente, sostiene el proyecto que "Siendo la libertad de culto o l libertad religiosa, una de las más preciadas libertades que tiene el ser humano para hacer prevalecer su libertad ideológica y su fe, es menester proteger este derecho desde la óptica penal, a fin de que no se transgreda o se ofenda los sentimientos de una persona o de los miembros de determinada confesión o creencia alguna, toda vez que en nuestra legislación penal, no se regula de manera exclusiva bajo ningún título o capítulo como bien jurídico protegido.

Que la religión predominante en el Perú es la católica (81,3\%), pero a la vez existen más de 150 Iglesias, misiones y asociaciones que están agrupadas en el Concilio Nacional Evangélico del Perú (CONEP) y que representan un 12,5\% de la población; así como otras religiones como los Mormones y Sectas Cristianas nuevas que agrupa a un 3,3\%, un 2,9\% que no especifican ninguna afiliación religiosa, además de otros cultos orientales, judíos y una comunidad del Isalm, muy pequeña. (Censo 2017)

Por esta razón, la tolerancia religiosa significa respetar y aceptar la existencia de otras formas de profesar la fe religiosa y como tal ser tolerante, implica una virtud moral que supone el respeto a la integridad humana y espiritual del otro, hacia sus ideas, prácticas y creencias, sin importar que sean contrarias a las nuestras.

En este sentido, es importante respetar las creencias de nuestro prójimo y ser capaces de comprender que todas las creencias son igualmente válidas y respetables para una convivencia armónica, basada en la libertad, el respeto y la justicia dentro de una sociedad organizada y respetuosa de sus tradiciones y Leyes, motivo por el cual es importante, la incorporación en nuestro Código Penal el delito contra la Libertad Religiosa y de Culto, a fin de evitar ofensas, agravios o insultos a la libertad de $\mathrm{fe}^{\prime \prime}{ }^{3}$

\footnotetext{
${ }^{3}$ http://derechoyreligion.uc.cl/es/docman/boletin-juridico/2018-1/1275-boletin-juridico-febrero-marzo-
} $\underline{2018 / \text { file\#page }=225}$ 